\title{
Tussle for Existence: An Inquisitive Exploration on the Role of Women in Sangati(Events)
}

\author{
Anju PS
}

\begin{abstract}
Indian society is quite a complex one, because of its construction of hierarchal social order grounded on the premise of sophistication, social order and sex. Historically, women are placed at the margins that prevented them from having opportunities and denied them the flexibility to enter the general public sphere. This paper entitled "Tussle for Existence: An Inquisitive Exploration on the Role of Women in Sangati (Events)" which is a close to the accurate attempt to discern the penetrating expertise of lower-class women who passed through many unconditional subjugations from varied norms of the society, as well as Dalit women's power of resilience to subdue these existing curtailments in the patriarchal social structure. Through the work, Sangati, Bama explores the lives of women, wherever caste and gender-based rights and rituals executed a women's life as sacrificial fires. In her work Sangati, Bama, one among the predominant Dalit women writers, constitutes the themes of Dalit feminism and the celebrations of self-assurance within the community of subaltern women.
\end{abstract}

Keywords: culture, gender oppression, marginalization, subaltern studies

\section{INTRODUCTION}

Manusmriti is meant to have the best influence in determining the functioning, additionally, because the structuring of the Indian

society conjointly delineates the roles of the four Varnas of the then Indian society: the Brahmins, the Kshatriyas, the Vaishyas, and the Shudras. A fifth class falls outside the group and consists of those referred to as "untouchables", Savarnas or Dalits. [1]

The term 'Dalit' has its roots in Sanskrit and the term "dal" means to separate, crack or open. Dalit needs to mean things or someone who is cut, split, torn or destroyed. To be Dalit within the twenty-first century is to still suffer social discrimination and restrictions unceasingly rebel, rise and question the oppressive scheme and order. Since the Government of Indian Act in 1935, Dalit's are formally referred to as scheduled castes. [2]

Dalit women are significantly badly affected not solely owing to their sex. However, additionally owing to non-secular, social and structural cultures those have given them all-time low strata within the social hierarchy. The taboo of untouchability makes them significantly vulnerable victims of every type of discrimination and atrocity. Within the sphere of education, health, wages, and legal

Revised Manuscript Received on April 15, 2020.

* Correspondence Author

Anju PS*, Department of English, Amrita Vishwa Vidyapeetham, Vallickavu, India. E-mail: anjups36@gmail.com

(c) The Authors. Published by Blue Eyes Intelligence Engineering and Sciences Publication (BEIESP). This is an open access article under the CC BY-NC-ND license (http://creativecommons.org/licenses/by-nc-nd/4.0/) rights, Dalit women are excluded from development policies that prevailed within the society.

Bama is a Tamil Woman writer, who has executed several literary works establishing sex and class based despotisms. Most of her works deal with, persistence, caste discrimination and gender oppression in the Dalit community.

\section{METHODOLOGY}

This present paper employs exploratory methodology in identifying patterns and themes of caste, class, culture and power of resilience in subaltern women community with reference to the work Sangati by Bama Faustina Soosairaj. Along with this primary data secondary materials regarding Dalit studies and literature are collected and implemented in this study.

\section{OBJECTIVES}

1. To evaluate the marginalization and gender discrimination of Dalit women community prevailed in the patriarchal society.

2. To trace the power of resilience and thereby the new renaissance within subaltern women community.

4. To document the importance of Dalit studies and literature in the present days.

\section{DATA ANALYSIS}

\section{1) Dalit studies:}

Dalit studies is a new field of research in India that looks at the problem of a marginalized group, namely, Dalits, tribals, physically challenged, women from excluded category and also similar groups in the social arena.

The main objectives of Dalit Studies are to attempt an assessment on diverse policies to vanquish sex-bias and its consequences, to undertake a study on the ultimate outcome of social elimination and classism in the field of economic development, education, health, and public participation, to establish global advancement and finance institution for authorizing them to structure the perspectives concerning the interdiction of an excluded group and to explicit considerable favors over authoritative bodies to advance the comprehensive policies.[3]

\section{2) Dalit literature:}

Dalit literature is a protest against the gender discrimination and subjugation of Dalits.

Published By:

Blue Eyes Intelligence Engineering \& Sciences Publication 
Equality and freedom are the key aspects that have been denied to Dalits and their touch, the voice and the shadow are considered impure. Because of the movement organized by Dr. Ambedkar, after independence, the Dalit community became aware of the need for equality and justice. The emergence of socio-political reprasentatives from this community results in the emergence of Dalit literature.

The influential work of Omprakash Valmiki's Jonathan was translated into English version by Arun Prabha Mukherjee gave a wider establishment in Dalit literature, in and outside India. No Alphabet in Sight which was edited by Suche Tharu and K. Sathyanaryanan flourished new thoughts on the history of Dalit literature and its prominence in the current scenario throws light into the essence of Dalit literature beyond other forms. [4]

\section{3) Sangati: An overview:}

In 1994, Laxmi Halmstrong was the one who translated the second novel of Bama, Sangati (Events) into English. The real life experiences of women characters are elucidated in the twelve sections of the novel. The title itself is extremely apt and suggestive of the trauma faced by Dalit communities. Bama, in her second work described a series of anecdotes in Tamil which have become a distinctive Dalit feminist narration of subjugation, tyranny, culture and gender oppression of the Paraiyar women community. Sangati is a distinctive narrative of Dalit feminism, predominantly associated with women's movement in India. This novel is full of interconnected events and everyday happenings of Dalit community. Bama, the Tamil Dalit feminist, a committed teacher, and writer, spoke directly, brazenly and bravely, with self-assurance and temperament relating to the multiple oppressions of Dalit ladies, regarding the yearning to measure life with exuberance, verity, and contentment regarding Women's arduous exertion. This novel Sangati is a real image of distinct facets of Dalit women's mode like different problems relating to severance in wedding, gender discrimination, sexual violence and caste-based oppression through the feminine characters.

Women are described in Sangati as wage earners. Dalit women participate in productive work and earn wages. But they are paid much less. Thereby Bama highlights social-feminism. They always carry the monetary burden of regulating family in a proper way. Women of Dalit community are perpetual victims of molestation and torcher from the field of labor. Bama exposes class, caste and cultural issues within the Dalit community. It is evident from this novel Sangati that, in most of the day's women remain like a slave within the socially constructed tag as a dutiful wife to clean, to cook and to feed hungry children and husband. Even after the hard toil within the four walls of the house and in the field, they cannot even sleep peacefully at night. They are forced to please their men at bed even though their body tormented with pain. When they revolt, it will result in violence or their death.

\section{4) Manifestation of women in Sangati:}

Sangati is a surprising view into the day-to-day struggles of several women of Dalit community, who dispute social subjugation and discrimination. The theme of the novel dwells on onerous labor and economic dangers that result in a culture of violence. Sangati is not just a tale of the pain of the oppressed women however a lot of significantly, celebrates their labor, identity, strength, and resilience. In this novel, Bama elucidates the brave Dalit women community, who are dare enough to mock the power structure within the society, thereby establish their will power to overcome the dark isolation in class and culture. Men are far apart from the conviction of responsibility as a husband, father and as a householder. However, the women of this community had to toil within the workplace and also as within the household.

From the time of birth, girls are discriminated simply because of sex. The abandonment of girl child from the infant stage in favor of the baby boy is clearly portrayed in Sangati. At the age of twelve, Bama recognizes an inadequate fact in games; boys have various entities while girls are perpetuated within some particular games. The women play gender roles like cooking, cleaning or marrying while 'kabadi' and 'marbles' are meant for boys.

Through the little girl child Maikkanni, Bama elucidates the fact that even a small girl child in the community cannot get rid of the male predominance, which results in dejection and despondency.

Deprivation and lack of attention from her father forced Maikkanni to take care of all the household things, while her mother works in the field. The frequent experiences of an adult woman are unconditionally pathetic much more than the mortifying experiences of a girl in Dalit community.

Bama relates the story of her grandmother Vellaiyamma, who is so ambitious and courageous sufficient to be a single parent despite of her uneducated and neglected status. Marriage is one among the fact that establishes the conventional regulation of gender-biased roles over women.

Women are denied the liberty to choose their marriage partner and the wedding has become organized via the families. Vellaiyamma establishes the will power to degrade the expectations regarding marriage as a social institution. By establishing the sturdy characters via her novel, Bama makes a new renaissance inside her community. Dalit women assort to various strategies to protest towards the subjugation prevailed in the society. While Mariamma attempts to withstand the conventional attitude of women by means of setting up her act against sexual molestation of an upper-caste fellow, Pachiamma protests by way of walking on without her husband. Bama establishes that Dalit women are always under menace and incessantly they are under the prospect of carnal abuse in work places. For Bama, Sangati is a tool for empowerment of women in Dalit community to move forward. We can trace Dalit women's celebration of new renaissance and self-assurance at the culmination of the novel. Though the struggle is much owing to the duel oppression of caste and gender, we can identify that the strength of the Dalit women community is so revealed.

As a feminist writer, despite establishing the dark bio-fold oppressions in the patriarchal society, Bama elucidates her women characters as the people who assert their identity and individualism through the path of resilience. Bama explores that, Dalit women are not shy rather they are fearless, unbiased and courageous. Through the novel Sangati, Bama holds a light into the mind and heart of women in Dalit community to make an enchantment for a change and betterment of the life of Dalit women in exclusive fields including, work, gender, caste, and sex.

Published By:

Blue Eyes Intelligence Engineering \& Sciences Publication

(C) Copyright: All rights reserved. 
The transfiguration of the Dalit women via the potentiality of resilience, to construct their milieu seems to be comparatively more preferable than the previous. Nobody will take an initiative to provide support, guidance or encouragement to the desperate women community of Dalit. The way to empowerment is within the hands of women themselves. Here, the words of Bama in Sangati, "We must not live like people who choose to be blind though they can see. If we ourselves do not change our condition, then who will come and change it for us?" [5](Bama, 2009)

Thus, Bama's Sangati can be appraised as a societal record of self-consciousness concerning the duel marginalization and the necessity for resistance. Sangati not only narrative portrayal social class and gender oppression but also develop a conviction of resistance and an alarm for exertions.

\section{V.CONCLUSION}

Dalit literature is a tenacious endeavor, to metamorphose the gloom-ridden framework connected with the class predominance, to an advanced milieu. The ultimate positive outcome of this newly generated vivacious scope has resulted in the reformulation in the critical facets of Dalit identity, and literature. Being in the midst of the outcomes of western literature and writers, Dalit writers portrayed their competent life experiences to establish awareness among individual Dalits by which it paves a way to the doors for the more youthful generation. Dalit literature concerns a self-contemplative path to explicit the subjugation, resilience as well as their self-consciousness of individuality.

Here the words of Limbale in the influential work, Towards an Aesthetics of Dalit Literature, "Dalit consciousness is an important seed for Dalit literature, it is separate and distinct from the consciousness of other writers. Dalit literature is unique because of this consciousness." [6] (Limbale, 2004)

\section{REFERENCES}

1. Wikipedia Contributors."Varna (Hinduism)". Wikipedia

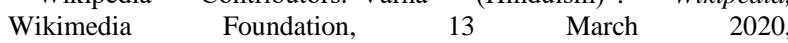
https://en.m.wikipedia.org/wiki/Varna(Hinduism). Web. Accessed15 March 2020.

2. Wikipedia Contributors "Dalit" Wikipedia, Wikimedia Foundation. 27 February 2020. https://en.m.wikipedia.org/wiki/Dalit. Web. Accessed 10 March 2020.

3. Agarwal, Kartika. "The Rise of Dalit Studies and Its Impact on the Study of India: An Interview with Historian Ramanarayan Rawat" AHA Blog. American Historical Association. 6 June 2016, www.historians.org/publications-and-directories/perspectives-on-hist ory/summer-2016/the-rise-of-dalit-studies-and-its-impact-on-the-stud y-of-india-an-interview-with-historian-ramnarayan-rawat.

4. Rajesh, Patchala. "Dr. B.R. Ambedkar: The Ultimate Inspiration for Dalit literature" International Journal of English Research. Research Gate, vol. 2, no. 5, Sept. 2016, pp. 3-5. WPS, www.researchgate.net $>3353$.

5. Faustina, Bama. " Sangati”, Translated by Lakshmi Holmstorm. New Delhi: Oxford HED, 2009.

6. Limbale, Sharankumar. "Towards an Aesthetic of Dalit Literature", Translated by Alok Mukherjee. Hyderabad: Orient Blackswan, 2004.

\section{AUTHORS PROFILE}

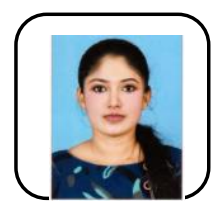

Anju PS, is a research scholar pursuing her Ph.D in the Department of English, Amrita Vishwa Vidyapeetham, Amritapuri Campus, Kollam, India She has participated and presented papers at various seminars and conferences. She has published articles in International Journals. 